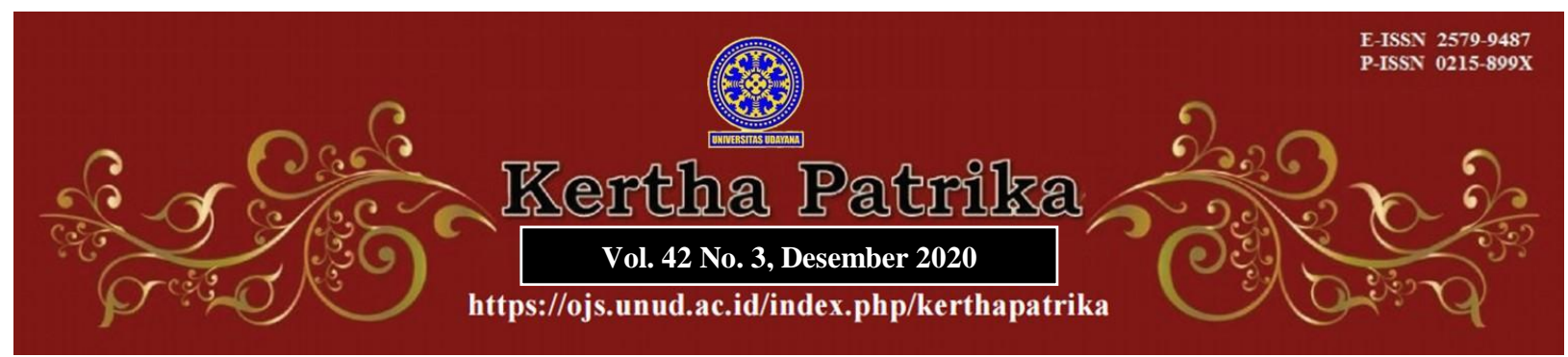

\title{
Legal Protection for Child Kidnapping Victims: Case Study in Gianyar District Court
}

\author{
Komang Suartana ${ }^{1}$, I Made Wirya Darma ${ }^{2}$
}

Faculty of Law and Social Science Undiknas University, E-mail: komangsuartana71@gmail.com

Faculty of Law and Social Science Undiknas University

E-mail :wiryadarma@undiknas.ac.id

\begin{tabular}{l}
\hline Info Artikel \\
\hline Submitted: $8^{\text {th }}$ December 2020 \\
Accepted : $9^{\text {th }}$ December 2020 \\
Published: $31^{\text {st }}$ December 2020 \\
Keywords: \\
Legal Protection; Child Victim, \\
Kidnapping; Gianyar District \\
Court \\
\\
Corresponding Author: \\
Komang Suartana \\
E-mail: \\
komangsuartana71@gmail.com \\
\\
DOI: \\
10.24843/KP.2020.v42.i03.p07
\end{tabular}

\begin{abstract}
This article aims to analyze how the crime of child kidnapping is covered in the Indonesian Criminal Code and the type of sanctions that can be imposed on the perpetrator of the crime of child kidnapping. It is a legal research that uses statutory, conceptual, and case approaches in discussing the legal protection of child kidnapping victims. In order to illustrate how the law that protects the victim of child kidnapping is applied by the court, it presents a case study at the Gianyar District Court that investigated a criminal offense of child kidnapping in 2018. The results reveal that the Indonesian Criminal Code classifies child kidnapping as a crime that is punishable as stipulated in Article 330 of the Code. In a more specific context, Law of the Republic of Indonesia Number 35 of 2014 concerning Amendments to Law Number 22 of 2003 concerning Child Protection includes child kidnapping as a case that needs to be given special protection A case study regarding the imposing of sanctions on the perpetrator of child kidnapping can be seen in a criminal case before the District Court of Gianyar in 2018. In the judgment, the panel of judges imposing a sentence against the defendant in the form of imprisonment of 8 (eight) years in prison and a fine of $R p$. 60,000,000 (sixty million rupiah) subsidiary 6 (six) months in prison;
\end{abstract}

\section{Introduction}

Children are an integral part of the family. Every child has rights as a human being since he/she is still in the womb. ${ }^{1}$. As children have dignity inherently, their human rights, among others, the right to live properly, to grow and develop optimally, to obtain

1 Manik, N. L. A., \& Widhiyaastuti, I. G. A. A. D. (2008). Penanganan Korban Tindak Pidana Penculikan terhadap Anak di Wilayah POLDA Bali. Kertha Wicara: Journal Ilmu Hukum, 8(12), $1-15$. 
protection, and to participate in matters relating to their fate as children, must always be upheld. ${ }^{2}$ Children are also the successor to the future of the nation once their physical, mental, and social growth have matured. ${ }^{3}$ Considering these levels of maturity, the protection of children must be differentiated from those applied to adults. ${ }^{4}$

Indonesia has made several important advances in formulating laws and legal instruments that defend children's interests. There has been Law Number 23 of 2002 concerning Child Protection as amended by Law Number 35 of 2014. Besides, there has been alsoLaw Number 23 of 2004 concerning the Elimination of Domestic Violence which stipulates that children are also protected as a subject.

Law Number 35 of 2014 concerning Amendments to Law Number 23 of 2002 concerning Child Protection emphasizes the obligation to provide child protection based on the principles of non-discrimination, the best interests of the child; appreciation for children's opinions and the right to life, survival, and development. ${ }^{5}$ In protecting children, the role of State, parents, family, and society, through child protection agencies, religious institutions, non-governmental organizations, community organizations, social organizations, the business world, mass media, and even judicial institutions. ${ }^{6}$, is needed. In the context of implementing child protection, the State is responsible for providing facilities and accessibility for children, especially in ensuring their growth and development.

It is classified that the younger generation is limited to a child aged 25 years, consists of childhood aged 0-12 years, adolescence aged 13-20 years, and adulthood aged 21-25 years. ${ }^{7}$ Further, childhood is divided into three stages, namely infancy between the ages of 0 to 2 years, the first childhood between 2 and 5 years of age, and the last childhood between the ages of 5 to 12 years.

There has been some research related to the topic discussed in this paper. Ni Luh Ayu Manik suggested that the form of handling that can be given to children who are victims of kidnapping crime is a form of handling assistance and forms of handling for restitution. As well as efforts that need to be made to improve the protection of children's

2 See Mulyadi, L. (2005). Pengadilan anak di Indonesia: teori, praktik, dan permasalahannya. Bandung: Mandar Maju, h. 4. and Sudrajat, T. (2011). Perlindungan Hukum Terhadap Hak Anak Sebagai Hak Asasi Manusia Dalam Perspektif Sistem Hukum Keluarga di Indonesia. Kanun Jurnal Ilmu Hukum, 13(2), 111-132.

3 See Prinst, Darwan. (2003). Hukum Anak Indonesia, Bandung: Citra Aditya Bakti, h. 4. And Said, M. F. (2018). Perlindungan Hukum Terhadap Anak Dalam Perspektif Hak Asasi Manusia. JCH (Jurnal Cendekia Hukum), 4(1), 141-152. DOI: http://doi.org/10.33760/ jch.v4i1.97.

4 Setiawan, A. (2019). Analisis Perlindungan Hukum Terhadap Anak Korban Penculikan Oleh Tenaga Pendidik di Lampung Selatan. Universitas Lampung.

5 General Explanation of Law Number 35 of 2014 concerning Amendments to Law Number 23 of 2002 concerning Child Protection

6 Al-Barry, Z. A. (2004). Hukum Anak-Anak dalam Islam, alih bahasa Chatijah Nasution. Jakarta: Bulan Bintang, h. 99.

7 Daradjat, Zakiah. (1980). Faktor-Faktor Yang Merupakan Masalah Dalam Proses Pembinaan Generasi Muda, Kertas Kerja Pada Simposium Aspek-Aspek Hukum Masalah Perlindungan Anak Dilihat Dari Segi Pembinaan Generasi Muda, diselenggarakan oleh Badan Pembinaan Hukum Nasional Kehakiman Republik Indonesian tanggal 24-26 Januari 1980 di Jakarta, h. 3. 
rights in dealing with victims of the crime of kidnapping are rehabilitation efforts for victims and the provision of procedural protections in court. ${ }^{8}$ Sendy Taruna Mukti Sugiyanto argued that the sanctions that can be imposed on children as perpetrators of child abductions can be reviewed from Law No. 3 of 1997 concerning Juvenile Court and Law No. 11 of 2012 concerning the Juvenile Criminal Justice System besides case studies of verdicts regarding the crime of kidnapping children. ${ }^{9}$ Research conducted by Ardi Putra Dewa Agung argued that the kidnapping of a child can be subject to criminal responsibility if the perpetrator has committed an act that fulfills the element of delinquency, and therefore, are subject to imprisonment and a fine. The criminalization of child kidnappers depends on the role of the judge when examining and hearing the case as they are given the freedom to determine the types of crimes, criminal acts, or high and low crimes. ${ }^{10}$

Based on the background of the problem above, the following problems can be formulated:

1. How is the crime of child kidnapping covered in the Indonesian Criminal Code?

2. What kind of sanctions can be imposed on the perpetrator of the crime of child kidnapping?

The present article discusses the legal protection of child kidnapping victims. In order to illustrate how the law that protects the victim of child kidnapping is applied by the court, it presents a case study at the Gianyar District Court that investigated a criminal offense that was executed by AHL, an Australian citizen, on 15 April 2018. The law enforcement agencies took action and brought him before the District Court of Gianyar. He has then imposed a sentence of 8 (eight) years in prison.

\section{Research Methods}

It is a legal research that uses statutory, conceptual, and case approaches. The primary legal materials were collected from legally binding legal materials, primarily the Indonesian Criminal Code and Law Number 35 of 2014 concerning Amendments to Law Number 23 of 2002 concerning Child Protection, and the decision of District Court of Gianyar. Secondary legal materials are in the form of all legal publications that are not official documents include textbooks and scientific articles.

\section{Results and Discussion}

\subsection{The crime of Child Kidnapping in the Indonesian Criminal Code}

Basically, children need assistance from adults in getting stimulus, learning, and education in a systemic and continuous process. They have certain developmental

Manik, N. L. A., \& Widhiyaastuti, I. G. A. A. D. (2008). Op.Cit., 1-15.

9 Sugiyanto, T. S. T. M. (2016). Tindak Pidana Penculikan Anak Yang Dilakukan Oleh Anak. Universitas Airlangga.

10 Agung, A. P. D., Sepud, I. M., \& Dewi, A. S. L. (2020). Sanksi Pidana terhadap Pelaku Penculikan Anak. Jurnal Preferensi Hukum, 1(2), 195-195. 
patterns and needs that are different from adults, so they cannot be treated like miniature adults. ${ }^{11}$

It is the right of every child to be free from acts of violence and free from content that contains violence, regardless of time and place. Thus, all parties are obliged to protect children from acts or content that contain violence. ${ }^{12}$

Indonesian Criminal Code covers offenses that are classified as kidnapping. The general provision is stipulated in Article 328 while the specific rule applies for child kidnapping is contained in Article 330.

Article 328 of the Criminal Code mentions as follows. "Any person who carries away a person from his place of residence or temporary residence with the intention of placing that person illegally under his or another's control, or to place him in a state of distress, is punished for kidnapping by a maximum imprisonment of twelve years." This article covers 4 (four) elements, both subjective and objective elements, namely a. whoever; $b$. taking someone away from their residence or temporary residence; c. Intention; and d. to place that person illegally under his or other people's power, or to put him in a state of distress.

To be applied in a specific case, this provision requires to prove that when the perpetrator takes away or kidnaps another person must have the intention of taking that person against the rights of one's power or the power of others, and can also be subject to punishment if the person who is kidnapped will be displaced. Meanwhile to detain or take people's freedom against their rights cannot be subject to this article, but it is subject to Article 333 of the Criminal Code.

Provisions regarding withdrawing a person who is underage from the predetermined power over him are regulated in the Criminal Code contained in Article 330 of the Criminal Code. This provision can be interpreted as a form of the abduction of children. Indeed, the article does not explicitly state that the article regulates kidnapping or not. However, if it is examined based on the phrase "taking away a child is not old enough from the power or supervision of an authorized person," it can be concluded that Article 330 of the Indonesian Criminal Code also regulates kidnapping. This is further emphasized by the provision of deception, violence, or threats of violence in paragraph 2 of Article 330 of the Code. Article 330 of the Criminal Code mentions as follows:

(1) Any person who deliberately takes away a person who is underage from the power determined by law or from the supervision of an authorized person shall be punished by a maximum imprisonment of seven years.

11 Daipon, D. (2017). Penculikan Anak (Antara Realitas dan Responsif Normatifnya menurut Pidana Islam). HUMANISMA: Journal of Gender Studies, 1(1), 13-23. DOI: http://dx.doi.org L10.30983/ih.v1i1.229.

12 Hz, E. D. (2012). Perlindungan Hukum Terhadap Anak Dari Konten Berbahaya Dalam Media Cetak Dan Elektronik. Jurnal Ilmu Hukum,4(1), 1-20. DOI: http://dx.doi.org L10.30652/jih.v3i1.1036 
(2) When deception, violence, or threats of violence are committed, or if the child is not yet 12 years old, the maximum imprisonment of nine years is imposed.

These are subjective and objective elements of Article 330 of the Indonesian Criminal Code and an explanation of each element.

a. Whoever;

A person who can be subject to this article is a person who escapes an underage person from the power of the person who has rights over the minor. Referred to as a person who is not yet mature in this case is a person who is not yet 21 years old or has never been married, either male or female.

b. Purposely;

The meaning of deliberate (opzet) is the maker wills and knows the action he is doing. Based on the distribution of the elements of error above, the aspect of error contained in the act of withdrawing a person who is underage from the predetermined power over him as regulated in Article 330 of the Criminal Code is the dolus (deliberate) element. This can be seen from the formulation of the article on kidnapping children which uses the phrase "... deliberately .....". The act of attracting someone underage by the perpetrator must be known and desired and the perpetrator knows the consequences arising from the act so that in this case there is no negligence.

c. Taking away a person who is underage from the power that is determined by law over him, or from the supervision of a person who has the authority to do so. What is meant by "attractive" can be related to Article 91 of the Indonesian Criminal Code where this article provides an understanding where the power of the father is the power of the head of the family, with the parents being defined as the head of the family and also by the father being defined as the person exercising the same power as the father.

Deception referred to in this article can be interpreted as clever tricks, tricks that can lure or trap the deceived person. When carrying out the process of kidnapping or "pulling" an underage child, the person must know that the person is not yet an adult. In this case, it did not need to be proven that the defendant knew that the child was less than twelve years old. Meanwhile, the violence referred to in this article can be linked to Article 89, namely making other people unconscious or helpless.

\subsection{Sanctions Imposed on The Perpetrators of The Child Kidnapping Crime}

Victims of crime are people who, individually or collectively, suffer losses as a result of their actions or do not do anything that violates the criminal law in force in a country, including regulations that violate the abuse of power. ${ }^{13}$

Violence against children is often not easy to reveal, because violence against children, especially within the family, is intrinsically personal. This is also supported by the community's perception that problems in the family are internal family matters that

13 Dwiatmodjo, H. (2011). Pelaksanaan Perlindungan Hukum terhadap Anak yang Menjadi Korban Tindak Pidana di Wilayah Hukum Pengadilan Negeri Banyumas. Jurnal Dinamika Hukum, 11(2), 201-213. DOI: http://dx.doi.org/10.20884/1.jdh.2011.11.2.91 
should not be interfered with. This perception creates a silent or passive attitude from the community around the child, so that the culture of physical violence against children continues and the child's survival becomes more threatened. It is time for parents to realize that children also have human rights like other adult human beings that must be respected.

Child protection is all activities to guarantee and protect children and their rights so that they can live, grow, develop, and participate optimally in accordance with human dignity, and receive protection from violence and discrimination. ${ }^{14}$ The low quality of child protection in Indonesia has drawn criticism from various elements of society. The conception of child protection covers a broad scope, in the sense that child protection is not only about the protection of the body and soul of the child, but also includes the protection of all their rights and interests that can ensure proper growth and development, both spiritually, physically and socially so it is hoped that Indonesian children will develop into adults who are capable and willing to work to achieve and maintain the goals of National Development. ${ }^{15}$ In the context of overcoming crime, various means are needed as a reaction that can be given to the perpetrators of crime, in the form of criminal and non-criminal sanctions, which can be integrated with one another. ${ }^{16}$

Besides Indonesian Criminal Law, Law of the Republic of Indonesia Number 35 of 2014 concerning Amendments to Law Number 22 of 2003 concerning Child Protection specify norms on child kidnapping. The law determines that everyone is prohibited from placing, letting, commit, ordering, or participating in kidnapping, selling, and/or trafficking of children. ${ }^{17}$ Regarding the sanction, Article 83 of Law of the Republic of Indonesia Number 35 of 2014 concerning Amendments to Law Number 22 of 2003 concerning Child Protection mentions every person who violates the provisions referred to in Article 76F shall be sentenced to imprisonment for a minimum of 3 (three) years and a maximum of 15 (fifteen) years and a fine of at least Rp. 60,000,000.00 (sixty million rupiah) and a maximum of Rp. 300,000,000.00 (three hundred million rupiah).

The Law also underlines that the government, local governments and other state institutions are obliged and responsible for providing special protection to children in the following situation: children in emergency situations; children in conflict with the law; children from minority groups and are isolated; children who are sexually and economically exploited; children who are victims of abuse of narcotics, alcohol, psychotropic substances and other addictive substances; children who are victims of pornography; children with HIV/AIDS; child kidnapping, sale, and/or trafficked; children who are victims of physical and/or mental abuse; children who are victims of sexual crimes; children who are victims of terrorism networks; children with disabilities;

14 Article 1 (2) of Law Number 23 of 2002 concerning Child Protection

15 Annisa, F. (2016). Penegakkan Hukum Terhadap Anak Yang Melakukan Tindak Pidana Pencabulan Dalam Konsep Restorative Justice. ADIL: Jurnal Hukum, 7(2), 202-211.

16 Djanggih, H. (2018). Konsepsi Perlindungan Hukum Bagi Anak Sebagai Korban Kejahatan Siber Melalui Pendekatan Penal Dan Non Penal. Mimbar Hukum-Fakultas Hukum Universitas Gadjah Mada, 30(2), 316-330. DOI: https://doi.org/10.22146/jmh.32017.

17 Article 76F of Law of the Republic of Indonesia Number 35 of 2014 concerning Amendments to Law Number 22 of 2003 concerning Child Protection 
children who are victims of abuse and neglect; children with deviant social behavior; and children who are victims of stigmatization of labeling related to conditions of his parents. ${ }^{18}$ It then becomes clear that child kidnapping shall be given special protection.

A case study regarding the imposing of sanctions on the perpetrator of child kidnapping can be seen in a criminal case before the District Court of Gianyar. As appears in Decision of District Court of Gianyar Number 108/Pid.Sus/2018/PN Gin, a criminal offense occurred in Bali in April 2018. The accused person is AHL (initial name), an Australian citizen-male, who has allegedly committed a crime of child kidnapping. The law enforcement agencies took action and brought him before the District Court of Gianyar which was then investigated and adjudicated such criminal case with ordinary examination procedures in the first instance. During the court proceeding, it was proven that the defendant (AHL) on April 152018 midnight committed a kidnapping of a child in a house situated in Nyuh Kuning sub-village, Mas village, Ubud-Gianyar. The defendant was accompanied by his friend who took away a male-baby aged 1 (one) year and 3 (three) months, after committing maltreatment to a person who stays together with the baby. They drove a car, taking away the baby to a rented house of the defendant, located in South Denpasar.

The Panel of Judges believes that all elements of Article 330 paragraph (2) of the Indonesian Criminal Code jo. Article 55 paragraph (1) of the Indonesian Criminal Code has been fulfilled, then the Defendant must be declared legally and convincingly proven to have committed a criminal act by taking part in kidnapping an immature person from the person who supervises him, that is conducted violently. In the trial, the panel did not find anything that could eliminate criminal liability as a justification and/or excuse, the accused must be accountable for his actions;

The panel also considers that the purpose of punishment is not as a retaliation for the criminal act committed by the defendant, but as an effort to educate and improve so that the accused in the future can become a better human being and this punishment is an effort to prevent the accused or other people from committing an act that has been committed by the defendant in this case; Subsequently, the panel taking into account Article 330 paragraph (2) KUHP Jo. Article 55 paragraph (1) to 1 of the Criminal Code and Law Number 8 of 1981 concerning Criminal Procedural Law.

In the judgment, the panel of judges declared that the defendant AHL is guilty for the criminal act of "placing, letting, committing, ordering or participating in kidnapping, selling and/or trafficking children", as regulated and punishable under Article 83 of Law No. 2014 concerning Amendments to Law Number 23 of 2002 concerning Child Protection. Therefore, the panel imposing a sentence against the defendant in the form of imprisonment of 8 (eight) years in prison and a fine of Rp. 60,000,000 (sixty million rupiah) a subsidy of 6 (six) months in prison;

18 Article 59 Law of the Republic of Indonesia Number 35 of 2014 concerning Amendments to Law Number 22 of 2003 concerning Child Protection 


\section{Conclusion}

Indonesian Criminal Code classifies child kidnapping as a crime that can be punished. The general provision is stipulated in Article 328 while the specific rule applies for child kidnapping is contained in Article 330. The code makes clear that any person who deliberately takes away a child from a person who is entitled to be responsible for the child shall be punished by a maximum imprisonment of seven years. The Code also allows imposing maximum imprisonment of nine years if deception, violence, or threats of violence are committed accordingly. In a more specific context, Law of the Republic of Indonesia Number 35 of 2014 concerning Amendments to Law Number 22 of 2003 concerning Child Protection includes child kidnapping as a case that needs to be given special protection The law also include sanctions to be imposed on the perpetrator of the criminal act of child kidnapping, shall be punished with imprisonment for a minimum of 3 (three) years and a maximum of 15 (fifteen) years and a fine of at least Rp. $60,000,000.00$ (sixty million rupiahs) and a maximum of Rp. 300,000,000.00 (three hundred million rupiahs). A case study regarding the imposing of sanctions on the perpetrator of child kidnapping can be seen in a criminal case before the District Court of Gianyar in 2018. In the judgment, the panel of judges imposing a sentence against the defendant in the form of imprisonment of 8 (eight) years in prison and a fine of Rp. $60,000,000$ (sixty million rupiah subsidiary 6 (six) months in prison.

\section{References}

\section{Books}

Al-Barry, Z. A. (2004). Hukum Anak-Anak dalam Islam, alih bahasa Chatijah Nasution. Jakarta: Bulan Bintang.

Hamzah, Andi. (2009). Delik Delik Tertentu (Speciale Delicten) di dalam KUHP. Cetakan Kedua. Jakarta: Sinar Grafika.

Mulyadi, L. (2005). Pengadilan anak di Indonesia: teori, praktik, dan permasalahannya. Bandung: Mandar Maju.

Prinst, Darwan. (2003). Hukum Anak Indonesia, Bandung: Citra Aditya Bakti.

Sunggono, Bambang. (2007). Metodelogi Penelitian Hukum, PT. Raja Grafindo, Jakarta.

\section{Journal}

Agung, A. P. D., Sepud, I. M., \& Dewi, A. S. L. (2020). Sanksi Pidana terhadap Pelaku Penculikan Anak. Jurnal Preferensi Hukum, 1(2), 195-195.

Annisa, F. (2016). Penegakkan Hukum Terhadap Anak Yang Melakukan Tindak Pidana Pencabulan Dalam Konsep Restorative Justice. ADIL: Jurnal Hukum, 7(2), 202-211.

Daipon, D. (2017). Penculikan Anak (Antara Realitas dan Responsif Normatifnya menurut Pidana Islam). HUMANISMA: Journal of Gender Studies, 1(1), 13-23. DOI: http://dx.doi.org /10.30983/jh.v1i1.229.

Djanggih, H. (2018). Konsepsi Perlindungan Hukum Bagi Anak Sebagai Korban Kejahatan Siber Melalui Pendekatan Penal Dan Non Penal. Mimbar HukumFakultas Hukum Universitas Gadjah Mada,30(2), 316-330. DOI: https://doi.org/10.22146/jmh.32017. 
Dwiatmodjo, H. (2011). Pelaksanaan Perlindungan Hukum terhadap Anak yang Menjadi Korban Tindak Pidana di Wilayah Hukum Pengadilan Negeri Banyumas. Jurnal Dinamika Hukum, 11(2), 201-213. DOI: http://dx.doi.org L10.20884/1.jdh.2011.11.2.91

Hz, E. D. (2012). Perlindungan Hukum Terhadap Anak Dari Konten Berbahaya Dalam Media Cetak Dan Elektronik. Jurnal Ilmu Hukum, 4(1), 1-20. DOI: http://dx.doi. org/10.30652/jih.v3i1.1036

Manik, N. L. A., \& Widhiyaastuti, I. G. A. A. D. (2008). Penanganan Korban Tindak Pidana Penculikan terhadap Anak di Wilayah POLDA Bali. Kertha Wicara: Journal Ilmu Hukum, 8(12), 1-15.

Rihardi, S. A. (2018). Perlindungan Hukum Terhadap Hak-hak Anak Perempuan Sebagai Korban Eksploitasi Seksual. Literasi Hukum, 2(1), 61-72.

Said, M. F. (2018). Perlindungan Hukum Terhadap Anak Dalam Perspektif Hak Asasi Manusia. JCH (Jurnal Cendekia Hukum), 4(1), 141-152. DOI: http://doi.org/ 10.33760/jch.v4i1.97.

Sudrajat, T. (2011). Perlindungan Hukum Terhadap Hak Anak Sebagai Hak Asasi Manusia Dalam Perspektif Sistem Hukum Keluarga di Indonesia. Kanun Jurnal Ilmu Hukum, 13(2), 111-132.

\section{Proceeding, Thesis and Scientific Papers}

Daradjat, Zakiah. (1980). Faktor-Faktor Yang Merupakan Masalah Dalam Proses Pembinaan Generasi Muda, Kertas Kerja Pada Simposium Aspek-Aspek Hukum Masalah Perlindungan Anak Dilihat Dari Segi Pembinaan Generasi Muda, diselenggarakan oleh Badan Pembinaan Hukum Nasional Kehakiman Republik Indonesian tanggal 24-26 Januari 1980 di Jakarta.

Setiawan, A. (2019). Analisis Perlindungan Hukum Terhadap Anak Korban Penculikan Oleh Tenaga Pendidik di Lampung Selatan. Universitas Lampung.

Sugiyanto, T. S. T. M. (2016). Tindak Pidana Penculikan Anak Yang Dilakukan Oleh Anak. Universitas Airlangga.

\section{Laws and regulations}

Kitab Undang-Undang Hukum Pidana

Undang-Undang Nomor 35 Tahun 2014 tentang Perubahan Atas Undang-Undang Nomor 23 Tahun 2002 tentang Perlindungan Anak. 